\title{
Emissions and photochemistry of oxygenated VOCs in urban plumes in the Northeastern United States
}

\author{
R. Sommariva ${ }^{1,2, *}$, J. A. de Gouw ${ }^{1,2}$, M. Trainer ${ }^{1}$, E. Atlas ${ }^{3}$, P. D. Goldan ${ }^{2}$, W. C. Kuster ${ }^{1}$, C. Warneke ${ }^{1,2}$, and \\ F. C. Fehsenfeld ${ }^{2}$ \\ ${ }^{1}$ Earth System Research Laboratory, NOAA, Boulder, CO, USA \\ ${ }^{2}$ CIRES, University of Colorado, Boulder, CO, USA \\ ${ }^{3}$ Rosenstiel School of Marine and Atmospheric Science, University of Miami, Miami, FL, USA \\ * now at: School of Environmental Sciences, University of East Anglia, Norwich, UK
}

Received: 29 May 2008 - Published in Atmos. Chem. Phys. Discuss.: 30 June 2008

Revised: 8 July 2011 - Accepted: 14 July 2011 - Published: 21 July 2011

\begin{abstract}
Photochemical processes inside urban plumes in the Northeast of the United States have been studied using a highly detailed chemical model, based upon the Master Chemical Mechanism (MCM). The model results have been compared to measurements of oxygenated VOCs (acetone, methyl ethyl ketone, acetaldehyde, acetic acid and methanol) obtained during several flights of the NOAA WP-3D aircraft, which sampled plumes from the New York City area during the ICARTT campaign in 2004. The agreement between the model and the measurements was within $40-60 \%$ for all species, except acetic acid.

The model results have been used to study the formation and photochemical evolution of acetone, methyl ethyl ketone and acetaldehyde. Under the conditions encountered during the ICARTT campaign, acetone is produced from the oxidation of propane $(24-28 \%)$ and i-propanol $(<15 \%)$ and from a number of products of i-pentane oxidation. Methyl ethyl ketone (MEK) is mostly produced from the oxidation of n-butane $(20-30 \%)$ and 3-methylpentane $(<40 \%)$. Acetaldehyde is formed from several precursors, mostly small alkenes, >C5 alkanes, propanal and MEK. Ethane and ethanol oxidation account, respectively, for $6-23 \%$ and $5-25 \%$ of acetaldehyde photochemical formation. The results highlight the importance of alkanes for the photochemical production of ketones and the role of hydroperoxides in sustaining their formation far from the emission sources.
\end{abstract}

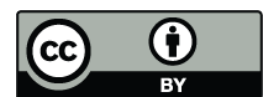

Correspondence to: J. A. de Gouw (joost.degouw@noaa.gov)

\section{Introduction}

Oxygenated Volatile Organic Compounds (VOCs) are important products of the photo-oxidation of hydrocarbons and other organic species in the atmosphere. Oxygenated VOCs include carbonyls (aldehydes and ketones), alcohols and carboxylic acids. It has been known for many years that these classes of compounds are ubiquitous in the atmosphere (Singh et al., 1994, 1995, 2000, 2001, 2004; Colomb et al., 2006; Müller et al., 2006) and may account for a large fraction of the organic carbon in the troposphere, with some studies suggesting that they might be 2 to 5 times more abundant than all the non-methane hydrocarbons combined (Singh et al., 2001, 2004). Some of these species have been shown to have a large impact on ozone formation and chemistry. Acetone, for example, is an important source of $\mathrm{HO}_{\mathrm{x}}$ radicals in the higher troposphere, where water concentration is low (Singh et al., 1995; McKeen et al., 1997; Jaeglé et al., 2001; Olson et al., 2004), and provides an important route to sequester active nitrogen in the form of peroxy acetyl nitrate (Singh et al., 1994, 1995; McKeen et al., 1997). In the lower atmosphere, carbonyls have been shown to be major radical sources, e.g. in winter-time polluted conditions (Emmerson et al., 2005) and in clean marine environments (Goldan et al., 2004; Sommariva et al., 2006; Madronich, 2006). More recently, oxygenated VOCs with multiple functional groups and low vapour pressure have been found to be important components of secondary organic aerosol both in laboratory and in field studies (Barsanti and Pankow, 2004; Hamilton et al., 2004; Odabasi and Seyfioglu, 2005; de Gouw et al., 2005; Madronich, 2006; Tong et al., 2006; Zhang et al.,

Published by Copernicus Publications on behalf of the European Geosciences Union. 
2007). Despite their relevance for many atmospheric processes, there are still many uncertainties and gaps in our understanding of the sources, sinks and chemistry of oxygenated compounds (Jacob et al., 2002; Singh et al., 2004), due to the large variety of different oxygenated VOCs encountered and to the difficulty of measuring them (Northway et al., 2004).

In addition to direct emissions, oxygenated VOCs are photochemically formed from the reactions of peroxy and alkoxy radicals ( $\mathrm{RO}_{2}$ and $\mathrm{RO}$, where $\mathrm{R}$ is a carbon chain) (Atkinson and Arey, 2003). The reactions between an organic peroxy radical and $\mathrm{HO}_{2}$ at low $\mathrm{NO}_{\mathrm{x}}$ (Reactions $\mathrm{R} 1, \mathrm{R} 2$ ) can result in the formation of an hydroperoxide (and a carboxylic acid in the case of an acyl peroxy radical) or a carbonyl. The reaction between two peroxy radicals at low $\mathrm{NO}_{\mathrm{x}}$ forms either two alkoxy radicals (Reaction R3) or a carbonyl and an alcohol (Reaction R4):

$$
\begin{aligned}
\mathrm{RCH}_{2} \mathrm{O}_{2} \cdot+\mathrm{HO}_{2} \cdot & \rightarrow \mathrm{RCH}_{2} \mathrm{OOH}+\mathrm{O}_{2} \\
\mathrm{RCH}_{2} \mathrm{O}_{2} \cdot+\mathrm{HO}_{2} \cdot & \rightarrow \mathrm{RCHO}+\mathrm{H}_{2} \mathrm{O}+\mathrm{O}_{2} \\
\mathrm{RCH}_{2} \mathrm{O}_{2} \cdot+\mathrm{R}^{\prime} \mathrm{CH}_{2} \mathrm{O}_{2} \cdot & \rightarrow \mathrm{RCH} \mathrm{O} \cdot+\mathrm{R}^{\prime} \mathrm{CH}_{2} \mathrm{O} \cdot+\mathrm{O}_{2} \\
\mathrm{RCH}_{2} \mathrm{O}_{2} \cdot+\mathrm{R}^{\prime} \mathrm{CH}_{2} \mathrm{O}_{2} \cdot & \rightarrow \mathrm{RCHO}+\mathrm{R}^{\prime} \mathrm{CH}_{2} \mathrm{OH}+\mathrm{O}_{2}
\end{aligned}
$$

Alkoxy radicals, which are formed by the reaction of an organic peroxy radical either with NO or with another peroxy radical (Reaction R3), are also known to form oxygenated hydrocarbons (Atkinson and Arey, 2003). Alkoxy radicals can react with $\mathrm{O}_{2}$ to form a carbonyl (Reaction R5) or decompose to form a carbonyl and an alkyl radical (Reaction $\mathrm{R} 6$ ). Reaction with $\mathrm{O}_{2}$ requires an hydrogen available on the radical carbon, so this path is not possible for tertiary alkoxy radicals (Atkinson and Arey, 2003). Depending on their molecular structure, some alkoxy radicals can also isomerize via a $1,5 \mathrm{H}$ atom shift to form an hydroxy alkyl radical (Reaction R7) which, upon reaction with $\mathrm{O}_{2}$, will form an hydroxy peroxy radical:

$$
\begin{aligned}
\mathrm{RCH}_{2} \mathrm{O} \cdot+\mathrm{O}_{2} & \rightarrow \mathrm{RCHO}+\mathrm{HO}_{2} . \\
\mathrm{RCH}_{2} \mathrm{O} \cdot & \rightarrow \mathrm{HCHO}+\mathrm{R} . \\
\mathrm{RCH}(\mathrm{O} \cdot) \mathrm{R}^{\prime} \mathrm{CH}_{3} & \rightarrow \mathrm{RCH}(\mathrm{OH}) \mathrm{R}^{\prime} \mathrm{CH}_{2} .
\end{aligned}
$$

The carbonyls formed in Reactions (R2), (R4), (R5) and (R6) are aldehydes, because their precursors are primary peroxy radicals; if the precursors are secondary or tertiary peroxy radicals, the carbonyl products will be ketones. Carbonyls, alcohols, hydroperoxides and carboxylic acids react with $\mathrm{OH}$ and with $\mathrm{NO}_{3}$. Some of these species, notably aldehydes and ketones, also photolyze. The products of these reactions are inorganic radicals and/or oxygenated peroxy radicals. Oxygenated peroxy radicals react further to produce multi-functional (alcohol + carbonyl) oxygenated compounds (Atkinson and Arey, 2003).
In the troposphere, the lifetime of oxygenates varies from a few hours $\left(\mathrm{HCHO}, \mathrm{CH}_{3} \mathrm{CHO}\right)$ to several days $\left(\mathrm{CH}_{3} \mathrm{OH}\right)$ to a few months (acetone). At sea-level, the lifetime of acetone with respect to $\mathrm{OH}\left(\tau_{\mathrm{OH}}\right)$ is 64 days and with respect to photolysis $\left(\tau_{\mathrm{h} v}\right)$ is 93 days, while for methyl ethyl ketone the two processes are approximately equal (12-13 days) (Baeza-Romero et al., 2005). Since they are both relatively long-lived species, they can be transported and act as radical sources initiating or enhancing photo-oxidation of other VOCs in remote regions and in the upper troposphere (McKeen et al., 1997; Wennberg et al., 1998).

Photochemical formation is not the only source of oxygenated VOCs. Anthropogenic and biogenic emissions, biomass burning, plant decay, dry and wet deposition also play an important role in the budget of oxygenates and are as important or more important than photochemistry (Jacob et al., 2002; Singh et al., 2004). For example, biogenic emissions are sources of methanol 3-5 times stronger than hydrocarbons oxidation, but the two processes are comparable for acetone and acetaldehyde (Singh et al., 2004). In urban areas, primary emissions are more important than photochemical production for some carbonyls, such as acetone, methyl ethyl ketone, methanol and ethanol (de Gouw et al., 2005). Much uncertainty lies in the role played by oceans. For example, several studies suggest that the ocean is a net sink for methanol (Carpenter et al., 2004; Singh et al., 2004; Lewis et al., 2005), but it is more uncertain whether the ocean is a net sink (Warneke and de Gouw, 2001; Jacob et al., 2002; Marandino et al., 2005) or a net source (Singh et al., 2004) for acetone.

Typically, chemical mechanisms do not treat in much detail the various formation pathways of secondary organic compounds, leading to the underestimation of their concentrations, with possible consequences on the estimates of ozone production chemistry in remote regions. In this work, a fully explicit chemical model was used to clarify the photochemistry of a number of oxygenated VOCs and, in particular, of the two most abundant ketones (acetone and methyl ethyl ketone) and of acetaldehyde.

This study refers to conditions encountered during the New England Air Quality Study (NEAQS) 2002 and the International Consortium for Atmospheric Research on Transport and Transformation 2004 field campaigns (ICARTT, Fehsenfeld et al., 2006), but the conclusions can be generalized to other similar urban environments. The model, the measurements and the conditions are described in Sect. 2 and the results are shown in Sect. 3. The carbonyls formation processes are analyzed in Sect. 4. During the discussion, some species will be indicated in the text with their MCM codenames (in italics), for simplicity. The corresponding chemical structures are shown in the diagrams of Sect. 4. A companion paper (Sommariva et al., 2008) contains a similar study for alkyl nitrates. 
Table 1. Initial values of model parameters $\left(\mathrm{CH}_{4}, \mathrm{CO}, \mathrm{NO}_{\mathrm{x}}\right.$ and $\mathrm{O}_{3}$ in ppbv, VOCs in pptv, temperature in $\mathrm{K}$, pressure in Pa).

\begin{tabular}{|c|c|c|c|}
\hline Parameter & Initial Value & Parameter & Initial Value \\
\hline $\mathrm{CH}_{4}$ & 1800 & acetylene & 837.1 \\
\hline $\mathrm{CO}$ & 332.5 & benzene & 143.6 \\
\hline $\mathrm{NO}_{\mathrm{X}}$ & 34.9 & toluene & 609.8 \\
\hline $\mathrm{O}_{3}$ & 90.0 & o-xylene & 106.7 \\
\hline ethane & 2701.1 & m-xylene & 134.7 \\
\hline propane & 1798.2 & p-xylene & 134.7 \\
\hline n-butane & 392.5 & ethylbenzene & 73.1 \\
\hline i-butane & 235.4 & n-propylbenzene & 18.8 \\
\hline n-pentane & 359.9 & i-propylbenzene & 5.7 \\
\hline i-pentane & 928.1 & 1,2,3-trimethylbenzene & 15.9 \\
\hline n-hexane & 249.2 & 1,2,4-trimethylbenzene & 81.3 \\
\hline 2-methylpentane & 257.2 & 1,3,5-trimethylbenzene & 21.1 \\
\hline 3-methylpentane & 296.7 & 1-ethyl-2-methyl benzene & 23.4 \\
\hline 2,2-dimethylbutane & 28.0 & 1-ethyl-3-methyl benzene & 40.5 \\
\hline 2,3-dimethylbutane & 61.7 & 1-ethyl-4-methyl benzene & 40.5 \\
\hline n-heptane & 92.5 & styrene & 5.9 \\
\hline 2-methylhexane & 89.6 & dichloromethane & 84.9 \\
\hline 3-methylhexane & 107.0 & chloroform & 2.6 \\
\hline n-octane & 45.7 & 1,1,1-trichloroethane & 44.4 \\
\hline n-decane & 23.3 & tetrachloroethene & 19.3 \\
\hline cyclohexane & 66.3 & methyl t-butyl ether & 560.4 \\
\hline ethylene & 1061.4 & formaldehyde & 1389.7 \\
\hline propylene & 317.0 & acetaldehyde & 694.8 \\
\hline 1-butene & 32.4 & propanal & 200.9 \\
\hline c-2-butene & 13.7 & n-butanal & 46.6 \\
\hline t-2-butene & 12.3 & n-pentanal & 18.5 \\
\hline 1-pentene & 26.0 & methanol & 1925.4 \\
\hline c-2-pentene & 11.5 & ethanol & 803.7 \\
\hline t-2-pentene & 22.6 & i-propanol & 161.9 \\
\hline 2-methyl-1-butene & 58.2 & acetone & 1004.6 \\
\hline 3-methyl-1-butene & 13.5 & methyl ethyl ketone & 217.7 \\
\hline$\alpha$-pinene & 22.1 & dimethyl sulphide & 12.5 \\
\hline$\beta$-pinene & 13.5 & temperature & 286.5 \\
\hline isoprene & 1740.5 & pressure & 84297 \\
\hline
\end{tabular}

\section{The model and the measurements}

\subsection{MCM model}

The model used in this work is similar to the ones used by Neuman et al. (2006); Roberts et al. (2007) and has been described in detail in Sommariva et al. (2008). It was built using a subset of version 3.1 of the Master Chemical Mechanism (MCM, http://mcm.leeds.ac.uk/MCMv3.1/). The MCM is one of the most detailed chemical mechanisms for tropospheric chemistry available (Jenkin et al., 1997; Saunders et al., 2003; Jenkin et al., 2003) and, therefore, it is very suitable to study the degradation and the formation of pollutants in the lower atmosphere.

The subset includes the oxidation mechanisms of 64 VOCs (including 14 oxygenated VOCs) plus $\mathrm{CH}_{4}, \mathrm{CO}$ and a complete inorganic mechanism taken from the 2003 IU-
PAC recommendation (Atkinson et al. (2003), http://www. iupac-kinetic.ch.cam.ac.uk/past_summary.html). The photolysis rates are calculated using the MCM parametrization (Saunders et al., 2003) for the end of July 2004 at the latitude and longitude of Boston (MA).

The model contains gas-phase chemistry only and no deposition to the surface or uptake of gas-phase species on aerosol. This is justified by the findings of previous field campaigns in the same area. During the NARE campaign, Daum et al. (1996) showed the formation of hydroperoxides $\left(\mathrm{H}_{2} \mathrm{O}_{2}\right)$ in photochemically aged plumes from the Eastern coast of the United States and Canada and found that these plumes were mostly contained in layers isolated from the surface by a low altitude temperature inversion; Neuman et al. (2006) showed that, during NEAQS 2004, nitric acid $\left(\mathrm{HNO}_{3}\right)$ was conserved in urban plumes decoupled from the marine boundary layer during the transport from New England to 
the ocean. Dilution is also neglected in the model, which does not matter if we are looking only at the chemical formation and evolution of certain species. The diluting effect can be taken into account when comparing the model results with the measurements (Sect. 3) by looking at enhancement ratios of the species of interest versus $\mathrm{CO}$. The enhancement ratio is defined here as the ratio of the enhancements in two species relative to their respective background values. While dilution typically decreases the mixing ratios with time, the enhancement ratios are less sensitive to dilution. This approach to separate the effects of chemistry from those of mixing has some limitations (McKeen and Liu, 1993; McKeen et al., 1996; Parrish et al., 2007), but it does provide a useful tool for data analysis (de Gouw et al., 2005, 2008).

\subsection{Conditions}

The model is initialized using measurements obtained during the NEAQS 2002 campaign (de Gouw et al., 2005) and the ICARTT campaign in 2004 (Fehsenfeld et al., 2006). The initial concentration of $\mathrm{NO}_{\mathrm{x}}$ is derived from the study by Neuman et al. (2006) and the initial concentrations of VOCs are derived from the emission ratios determined by de Gouw et al. (2005); Warneke et al. (2007). The details of the procedure used to calculate the emission ratios are explained in Sect. 2.3. The initial concentration of $\mathrm{CO}$ is set to a typical value measured in the Boston area during ICARTT, using an acetylene/CO ratio of $3.6 \mathrm{pptv} \mathrm{ppbv}^{-1}$ (Warneke et al., 2007) with an estimated background [CO] of $100 \mathrm{ppbv}$. The initial concentrations of $\mathrm{CH}_{4}$ and $\mathrm{O}_{3}$ are estimated to be $1800 \mathrm{ppbv}$ and $90 \mathrm{ppbv}$, respectively.

The initial concentrations of the species included in the MCM model are shown in Table 1 (see also Sommariva et al., 2008). The model is run for 5 days to simulate the evolution of the chemical composition of a typical urban plume. The model results (Sect. 3) are then compared with measurements of oxygenated VOCs obtained on board the NOAA research aircraft WP-3D during the ICARTT campaign.

The model results are shown in Fig. 1. The calculated concentrations of radicals $\left(\mathrm{OH}, \mathrm{HO}_{2}, \mathrm{NO}_{3}\right)$ vary diurnally and show a general increase with time. The increase in $\left[\mathrm{HO}_{\mathrm{x}}\right]$ is driven by the build-up of ozone concentration during the 5 days, as well as the decrease of $\mathrm{HO}_{\mathrm{x}}$ loss terms $\left(\mathrm{NO}_{\mathrm{x}}\right.$ and VOCs). The model also shows the comparatively fast removal of $\mathrm{NO}$ and $\mathrm{NO}_{2}$ and the consequent formation of $\mathrm{HNO}_{3}$ via the reaction of $\mathrm{NO}_{2}$ with $\mathrm{OH}$, in accord with the findings by Neuman et al. (2006). After the second day, $\left[\mathrm{NO}_{\mathrm{x}}\right]$ decreases below 1 ppbv. The concentration of $\mathrm{NO}_{2}$ after the second day is however enough to form $\mathrm{NO}_{3}$ via the reaction with increasingly high $\mathrm{O}_{3}$, which allows the continuation of night-time processing of VOCs during the following nights.
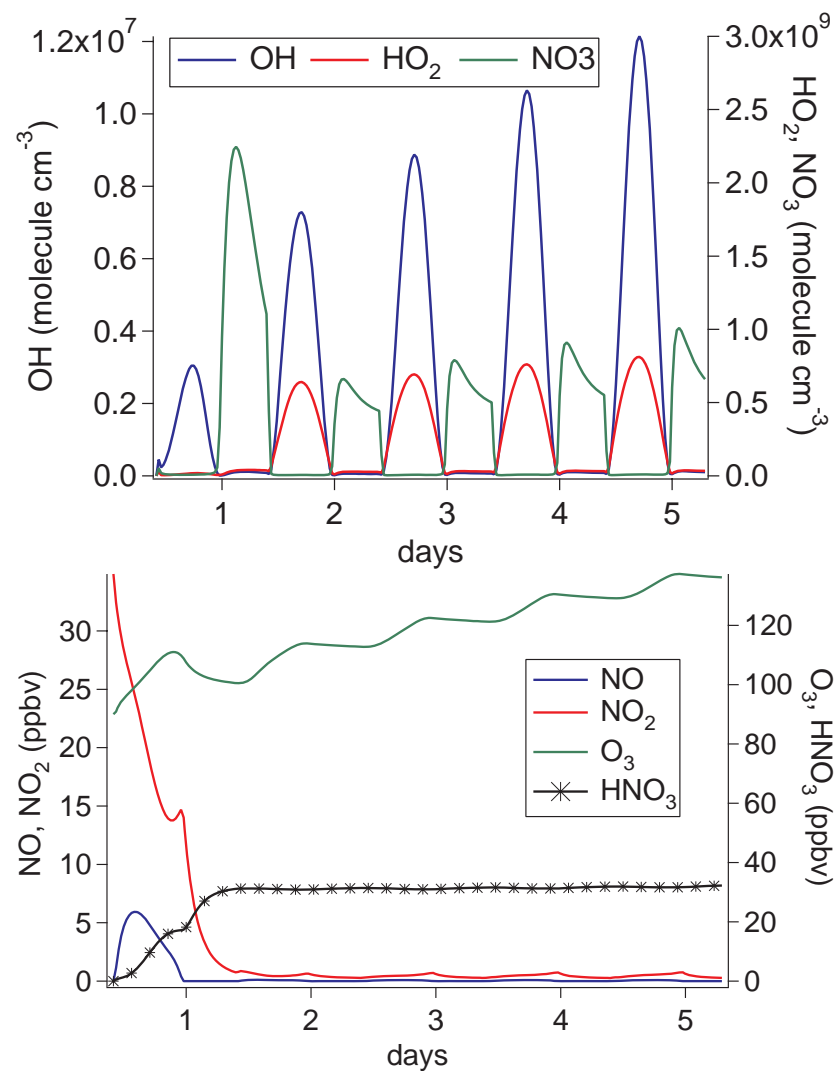

Fig. 1. Modelled concentrations of radicals (a), $\mathrm{O}_{3}, \mathrm{NO}_{\mathrm{x}}$ and $\mathrm{HNO}_{3}$ (b).

\subsection{NEAQS parametrization}

In a previous paper, de Gouw et al. (2005) derived the time evolution of VOCs and organic aerosol in air masses along the coast of New England by describing the measured data with a semi-empirical parametrization that includes (1) urban emissions of VOCs and the removal of those VOCs by $\mathrm{OH}$, (2) secondary formation and removal of oxygenated species, (3) a biogenic term parameterized by measured isoprene and its photo-oxidation products and (4) a background concentration. The measurements were obtained during the NEAQS 2002 campaign (July-August 2002) onboard the NOAA research vessel Ronald H. Brown, downwind from the Boston and New York metropolitan areas.

The time evolution of VOCs in a typical urban plume can be calculated using Eq. (5) and the numbers in Table 1 of de Gouw et al. (2005), assuming that the biogenic term is negligible directly inside the plume, i.e. omitting the third term in Eq. (5). The results for acetone, methyl ethyl ketone (MEK), acetaldehyde, acetic acid and methanol are presented in Fig. 2, which shows the enhancement ratios of these species versus $\mathrm{CO}$ as a function of the photochemical age. The latter was calculated from measured 


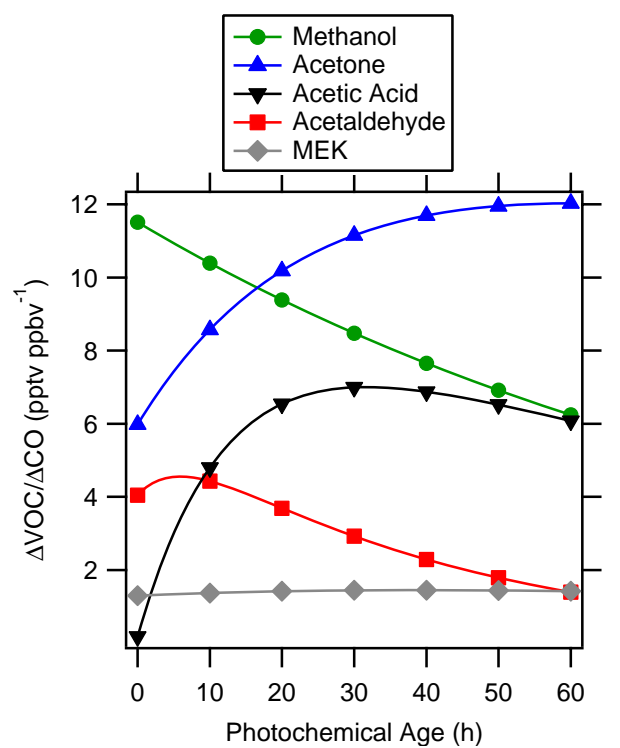

Fig. 2. Time evolution of oxygenated VOCs in a typical urban plume according to de Gouw et al. (2005). Curves are calculated using Eq. (5) and the numbers in Table 1 of de Gouw et al. (2005).

benzene/toluene ratios and a constant $\mathrm{OH}$ concentration of $3 \times 10^{6}$ molecule $\mathrm{cm}^{-3}$, which explains why there is no diurnal variation in the removal and formation of the species in Fig. 2.

In de Gouw et al. (2005), VOC enhancement ratios were given with respect to acetylene; those have been converted here into enhancement ratios versus $\mathrm{CO}$ as described in de Gouw et al. (2008). The acetylene/CO emission ratios are different in de Gouw et al. (2005) (4.94 pptv ppbv ${ }^{-1}$ ) and in Warneke et al. (2007) (3.6 pptv ppbv $\left.{ }^{-1}\right)$, thus introducing an uncertainty in the conversion, which will be further discussed below. In the present paper (Sect. 3), we have compared the curves shown in Fig. 2 to the data from ICARTT and to the MCM model results. The implicit assumption in this comparison is that the photochemical age in Fig. 2 is in fact equal to the processing time in the model and of the sampled air masses. The average $\mathrm{OH}$ concentration of $3 \times 10^{6}$ molecule $\mathrm{cm}^{-3}$, which was used to calculate the photochemical age in de Gouw et al. (2005), has an uncertainty of about a factor of 2 , which will also be taken into account in the comparison.

While we have ignored the biogenic source of oxygenated VOCs in calculating the curves shown in Fig. 2, the model includes isoprene - as well as monoterpenes - because these species are typically present in urban areas. Based on the initial isoprene concentration in Table 1 , and on the oxygenatesto-isoprene ratios in (de Gouw et al., 2005) (Table 1 in that paper), we estimate the biogenic contributions to oxygenated VOCs to be $\sim 800$ pptv for methanol, $\sim 100$ pptv for acetaldehyde, $\sim 400$ pptv for acetone, $\sim 50$ pptv for MEK and $\sim 300$ pptv for acetic acid. For methanol, acetaldehyde, ace- tone and MEK, these values are smaller but not negligible compared to the initial conditions in Table 1. For acetic acid, this contribution is larger, as acetic acid is assumed to have zero anthropogenic emissions, but as shown below, $\sim 300$ pptv is significantly lower than the acetic acid observed in aged plumes.

\subsection{Measurements}

Oxygenated VOCs were measured during ICARTT using a Proton Transfer Reaction Mass Spectrometer (PTR-MS) onboard the NOAA WP-3D aircraft (de Gouw et al., 2006; de Gouw and Warneke, 2007). In this study, we use the data for acetone, methyl ethyl ketone (MEK), acetaldehyde, acetic acid, methanol, benzene and toluene, which were sampled for $1 \mathrm{~s}$ each every $17 \mathrm{~s}$. The detection limit of the instrument is estimated from the $2 \sigma$ noise in the background measurements and varied between $30 \mathrm{pptv}$ for aromatic species to 300 pptv for methanol, depending on ion count rates and system backgrounds as described by de Gouw and Warneke (2007). The calibration accuracy of the measurements is estimated to be $15 \%$ for most species and $50 \%$ for acetic acid.

The other VOCs (alkanes, alkenes, acetylene, aromatics, dimethyl sulphide, methyl t-butyl ether, halogenated hydrocarbons) were measured by Gas Chromatography coupled to a Mass Spectrometer detector (GC-MS) after collection in stainless steel canisters (Schauffler et al., 1999; Reeves et al., 2007). A description of the other instruments on board the WP-3D can be found in Fehsenfeld et al. (2006); Neuman et al. (2006).

\section{Results}

During the ICARTT campaign the NOAA WP-3D aircraft sampled the outflow from New York City during multiple flights, at different times of the day and at various distances from the sources. In this study, we have used the data from six different flights. Figure 3 shows the portions of the flights during which the outflow from New York City was sampled. The flight tracks are color-coded by the measured mixing ratio of CO, which varied between 200 and 400 ppbv in the plumes. On 7 August, a flight was started in the evening hours, which sampled the outflow from New York City at a time of minimal processing by $\mathrm{OH}$. On, 20 and $25 \mathrm{July}$, the NOAA WP-3D flew shortly downwind from New York City during the day. The outflow from New York City after one day of processing was sampled over the Atlantic Ocean on 21 July and 14 August, and after two days of processing on 22 July near Nova Scotia. The FLEXPART footprint analysis of these plumes (Stohl et al., 2003) indicated that most of the sampled emissions were from New York City. To further illustrate this point, Fig. 3 contains back trajectories for the three flights furthest away from New York City. In each case, 


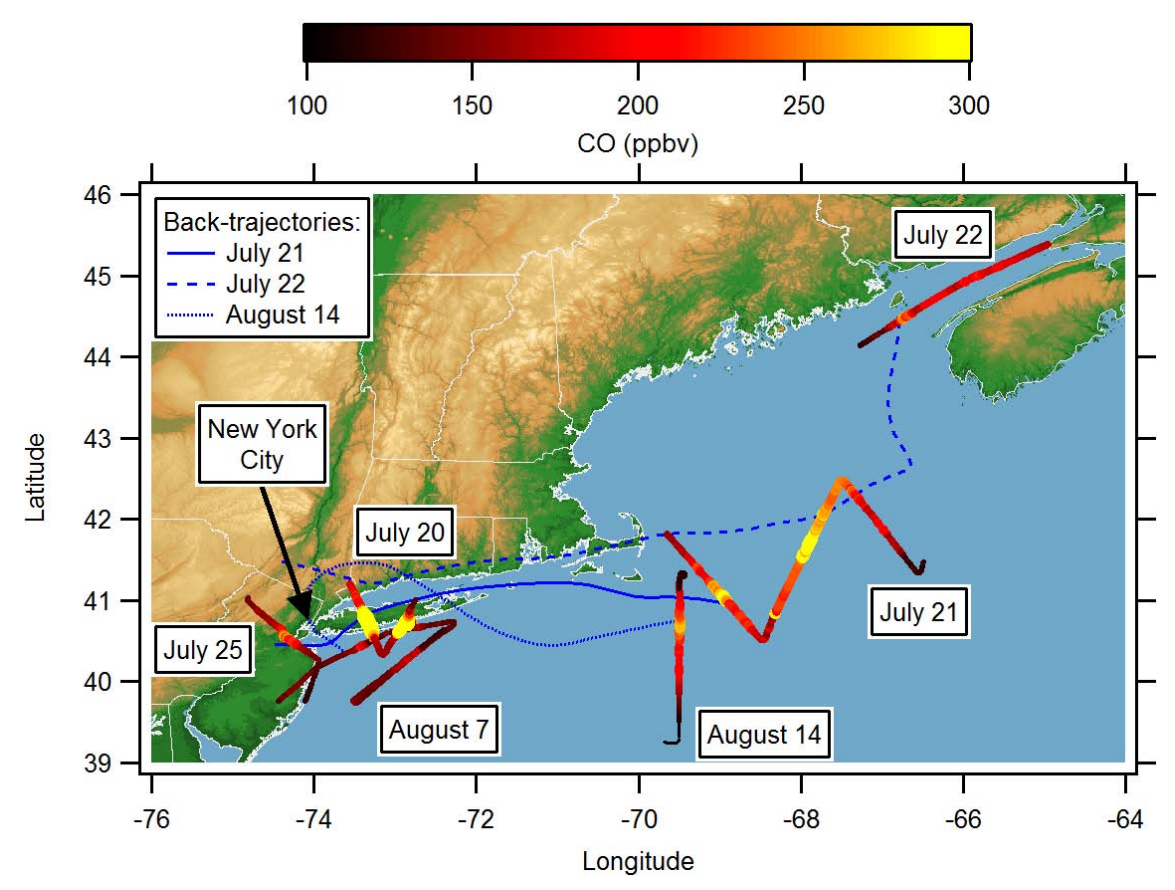

Fig. 3. Portions of the flight tracks from the NOAA WP-3D aircraft on six different days, during which the outflow from New York City was sampled. Back trajectories for three of the sampled plumes are also shown.

the back trajectory traces back to New York City within a few tens of kilometers.

In each sampled plume, the oxygenated VOCs as well as benzene and toluene were typically well correlated with $\mathrm{CO}$, which is used here as an inert tracer for urban emissions. Examples are shown in Fig. 4, which contrasts the observations at night (7 August) with those after one day of processing (21 July). Assuming that urban emissions were roughly the same as during the day-time flights, the nighttime observations of the 7 August flight can be considered as representative of unprocessed air, even though aged plumes were occasionally sampled during the flight. The enhancement ratios, $\triangle \mathrm{VOC} / \triangle \mathrm{CO}$, are determined from the slopes of linear regressions to the data. Figure 4 shows marked differences between the enhancement ratios determined from the two flights. Toluene, which has a lifetime of 1-2 days, has a much higher enhancement ratio at night on 7 August than after 1 day of processing on 21 July. For several oxygenated VOCs (acetone, MEK and acetaldehyde) the opposite is observed: their enhancement ratios are significantly lower at night. Methanol and benzene are relatively inert and show similar enhancement ratios on both flights. Methanol and acetic acid typically show the lowest degree of correlation with $\mathrm{CO}$, possibly caused by the importance of biogenic sources of these species that are, of course, not correlated with the urban emissions (see Sect. 2.3 and de Gouw et al., 2005). Despite a lower correlation, acetic acid typically shows lower enhancement ratios in unprocessed air masses as also seen in Fig. 4. While we cannot rule out that the dif- ferences between the day-time and night-time flights are due to differences in emissions, the more likely explanation is that these differences are related to chemical processing and they will be interpreted as such in this study.

Figure 5 summarizes the enhancement ratios from all six flights shown in Fig. 3. For the most straightforward comparison with the MCM model, the data are plotted as a function of the numbers of hours since sunrise on the day of emission. We take this time since sunrise rather than the atmospheric transport time to reflect the fact that when measuring inside an urban air shed during the day, the hydrocarbon mixture is always aged to a significant extent. The enhancement ratios obtained during the nighttime flight (7 August) are shown at zero hours and represented by the solid circles; the open circles represent the results from the daytime flights. For the inert species methanol and benzene, the data show a gradual decrease over the course of two days of processing. For the much more reactive toluene, the removal was much faster. For the two ketones, the data show a gradual increase for acetone and a rapid increase for MEK as a result of processing. The data show a rapid increase of acetaldehyde on the first day and then a gradual decrease with time. Finally, for acetic acid a gradual increase during the first day was observed.

The measurement data in Fig. 5 are overlaid with (1) the results from the MCM model (solid curves), and (2) the parametrization of VOCs versus photochemical age derived from data obtained during NEAQS 2002 (de Gouw et al., 2005) (grey area). A range of values is shown here rather than the curves in Fig. 2 to reflect the uncertainties in the 

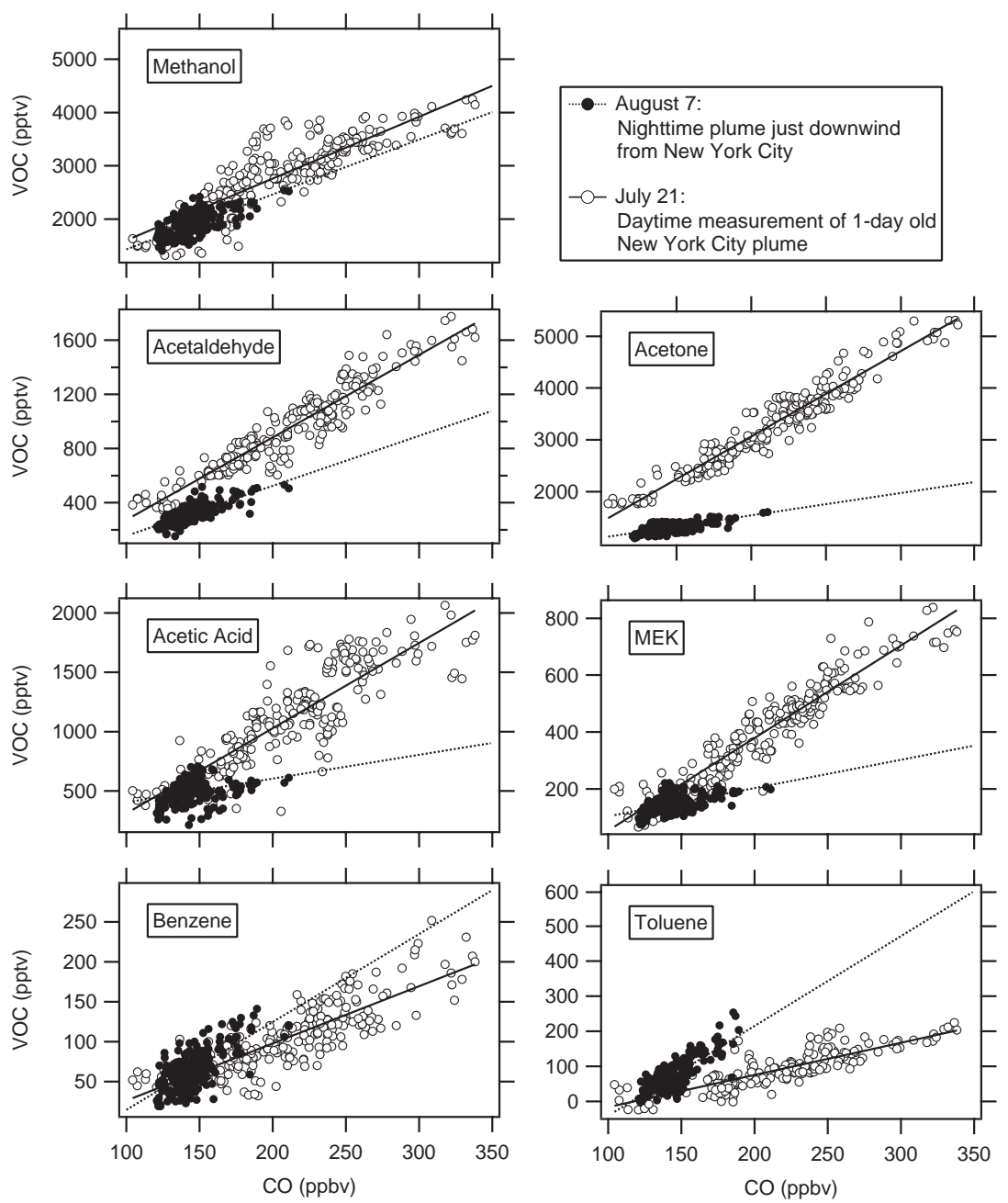

Fig. 4. Scatter plots of VOCs versus CO for the flights from 7 August, during which the outflow from New York City was sampled at night, and 21 July, after 1 day of processing.

acetylene/CO emission ratio and in the average $\mathrm{OH}$ concentrations as explained in Sect. 2.3. Because the NEAQS parametrization assumes a constant concentration of $\mathrm{OH}$, the parametrization curves are smooth in time, whereas the MCM model shows different rates of oxidation at night and during the day. Also shown in Fig. 5 are the emission ratios according to Warneke et al. (2007). For methanol, acetaldehyde and benzene these ratios are somewhat lower than the initial values assumed in this work. Rather than actual differences in emissions, we believe these differences more likely reflect the uncertainties in determining emission ratios from a data set obtained outside an urban air shed. For acetone, acetic acid, MEK and toluene the emission ratios from (Warneke et al., 2007) agree quite well with the initial values in Table 1.

It is clear from Fig. 5 that the MCM model agrees well in an average sense with the NEAQS parametrization and the data from ICARTT, except for acetic acid, which is formed in much larger quantities than is accounted for by the chemistry included in the MCM. Both the MCM model and the NEAQS parameterizations describe the trends in the ICARTT data for the other species reasonably well, although they underestimate the formation of acetaldehyde and MEK during the first day. This may be caused by the relatively low $[\mathrm{OH}]$ in the MCM model on the first day (Fig. 1). The agreement between the MCM model and the measurements is within $40-60 \%$ for all the species, except acetic acid.

The acetic acid concentration calculated by the MCM model underestimates the measurements by a factor of 5 or more, although the NEAQS parametrization describes the measurements quite well (Fig. 5). In the MCM, acetic acid is formed in two ways: by reaction of the $\mathrm{CH}_{3} \mathrm{C}(\mathrm{O}) \mathrm{O}_{2}$ radical with $\mathrm{RO}_{2}\left(\mathrm{HO}_{2}\right.$ or another organic peroxy radical $)$ and by ozonolysis of C3-C6 alkenes, forming the Criegee biradical $\mathrm{CH}_{3} \dot{\mathrm{C}} \mathrm{HOO}$. which then reacts with $\mathrm{H}_{2} \mathrm{O}$ to form acetic acid. The former process can occur only when $\mathrm{NO}_{\mathrm{x}}$ levels are 

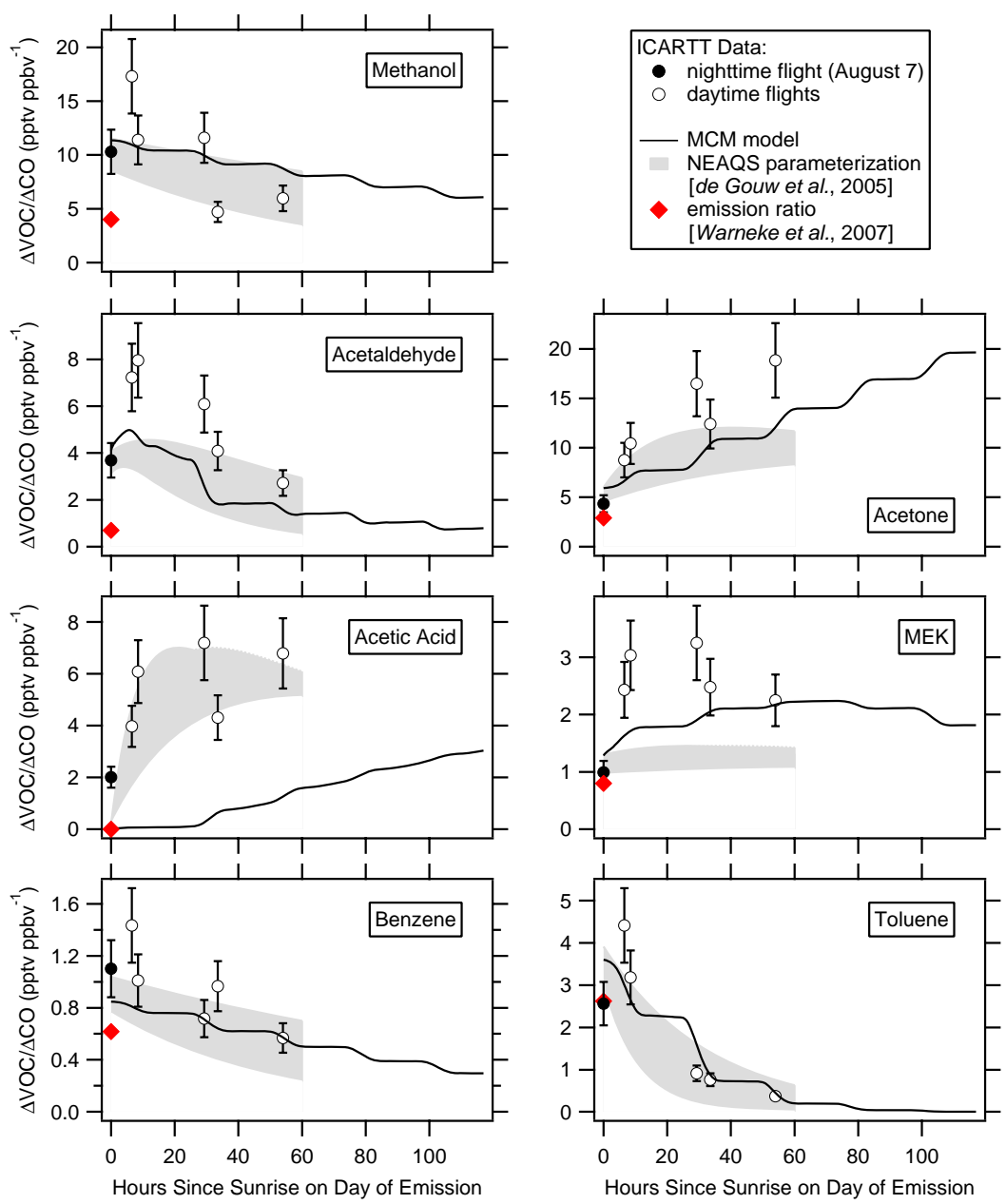

Fig. 5. Measured VOC enhancement ratios from six different flights downwind from New York City as a function of the transport time. Also shown are the calculation of the VOC enhancement ratios as a function of processing time using the MCM model (solid curve), the NEAQS parameterization (Fig. 2) of enhancement ratios as a function of photochemical age - with the grey area representing the range of possible values due to uncertainties in average $\mathrm{OH}$ and in the acetylene/CO emission ratio - and the emission ratio according to Warneke et al. (2007).

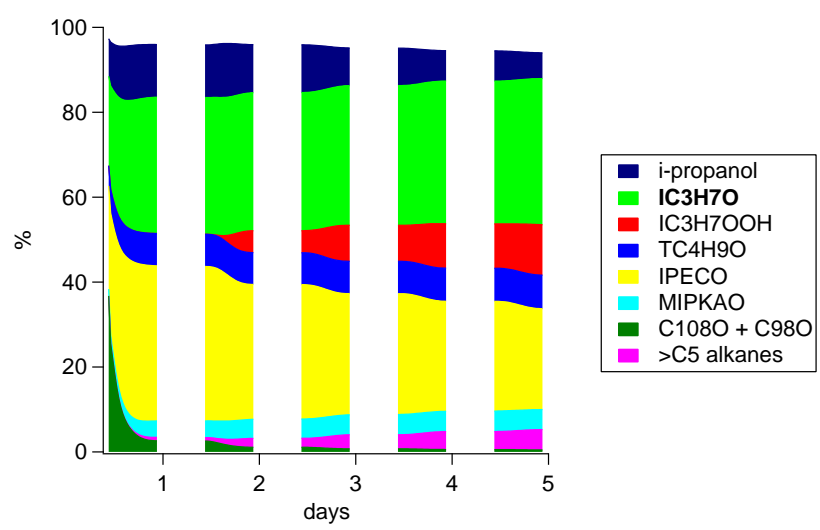

Fig. 6. Relative contribution of reaction pathways to the formation of acetone. See Fig. 7 for explanation of the MCM codenames. sufficiently low (Fig. 1); the latter process is too slow to form significant amounts of acetic acid during the day, because alkenes are very reactive to $\mathrm{OH}$ and their concentrations decrease rapidly during the first day. Therefore, under the conditions used in this work, the MCM predicts significant formation of acetic acid only during the second day (Fig. 5). The rate coefficients for the formation (via $\mathrm{CH}_{3} \mathrm{C}(\mathrm{O}) \mathrm{O}_{2}+$ $\mathrm{RO}_{2}$ routes) and destruction (via reaction with $\mathrm{OH}$ ) reactions of acetic acid in the MCM are $\sim 40 \%$ lower and $\sim 8 \%$ higher, respectively, than the 2003 IUPAC recommendation (Atkinson et al., 2003). This cannot account for such a large discrepancy, especially during the first day. Direct formation of acetic acid following the addition of $\mathrm{OH}$ to acetone is not included in the MCM. However, laboratory studies (Turpin et al., 2006) indicate that the branching ratio for this reaction is small $(<0.05)$, which could not account for the observed discrepancy. 


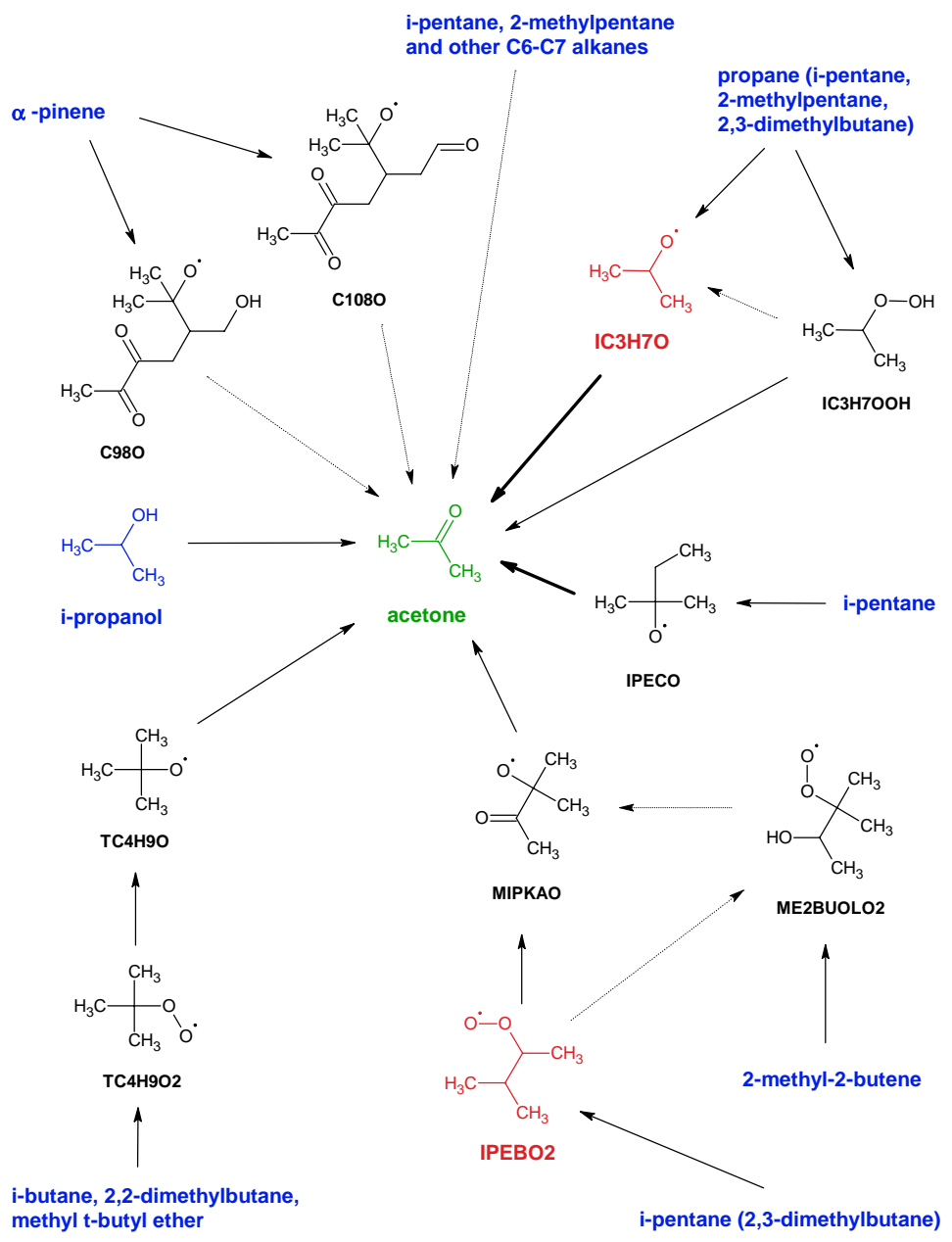

Fig. 7. Reaction scheme for the formation of acetone. Green indicates the target species, blue indicates the VOC precursors and red indicates an intermediate analyzed in detail in Sommariva et al. (2008).

The inability of chemical models to reproduce measured concentrations of acetic acid has been known for some time (e.g., Madronich et al., 1990; Jacob et al., 1992; Talbot et al., 1995; Ito et al., 2007). There is still considerable uncertainty in our understanding of acetic acid budget (Singh et al., 2000): biomass burning (Helas et al., 1992; Talbot et al., 1992, 1999; Yokelson et al., 1999; de Gouw et al., 2006; Ito et al., 2007) and biogenic emissions (Klemm et al., 1994; Talbot et al., 1995; Kesselmeier, 2001) have been proposed as major sources of acetic acid. However, it must be noted that the measurements shown in Fig. 5 were filtered to eliminate the biomass fire plumes and that the emission ratio for acetic acid is assumed to be zero in this work (de Gouw et al., 2005). This suggests that the discrepancy between the model and the measurements may be attributed either to missing direct emissions (likely biogenic) or to an unknown gas-phase or heterogeneous production mechanism (Nolte et al., 1997; Turpin et al., 2006).

\section{Photochemical formation of ketones}

The MCM contains a very detailed description of the oxidation processes of most of the known emitted VOCs (Jenkin et al., 1997; Saunders et al., 2003). The mechanism is by no means complete, but it reflects the current understanding of tropospheric chemical processes and allows to follow the formation and the degradation pathways of a species down to $\mathrm{CO}_{2}$ and $\mathrm{H}_{2} \mathrm{O}$, taking into account all the known photochemical sources and sinks. In the following sections the formation pathways of acetone, methyl ethyl ketone (MEK) and acetaldehyde will be discussed in detail and their relative importance assessed.

\subsection{Acetone}

The photochemical formation of acetone involves a large number of routes, though only a few of them contribute by more than a few percent to the total production rate. The relative importance of each pathway does not change 
significantly from day to day, with the exception of the first day, during which a significant contribution $(\sim 10 \%$ on average) comes from the decomposition of $\alpha$-pinene derived alkoxy radicals (Figs. 6 and 7).

The two major photochemical sources of acetone are the decomposition of the alkoxy radical IPECO and the reaction of the alkoxy radical $I C 3 H 7 O$ with $\mathrm{O}_{2}$ (Fig. 7). The former accounts for $30-35 \%$ and is a product of i-pentane oxidation, while the latter accounts for $35 \%$ on the first day down to $25 \%$ on the fifth day of the total acetone formation (Fig. 6). Sommariva et al. (2008) have analyzed the formation processes of the peroxy radical $\mathrm{IC} 3 \mathrm{H} 7 \mathrm{O} 2$, which is the only significant precursor of $I C 3 H 7 O$. A small fraction of this alkoxy radical is produced via photolysis of the hydroperoxide $\mathrm{IC} 3 \mathrm{H} 7 \mathrm{OOH}$, which is formed starting from the second day when $\mathrm{NO}_{\mathrm{x}}$ has been largely removed (Fig. 1). The hydroperoxide is, however, more likely to directly form acetone via reaction with $\mathrm{OH}$ (which is faster than photolysis) and contributes in this way to acetone formation for $<10 \%$ (Fig. 6).

According to the analysis by Sommariva et al. (2008), who used the same model and the same initial conditions, about $80 \%$ of the peroxy radical $\mathrm{IC} 3 \mathrm{H} 7 \mathrm{O} 2$ is produced via the reaction of propane with $\mathrm{OH}$ over the five days run of the model simulation. The rest comes from the oxidation of i-pentane, 2,3-dimethylbutane, 2-methylpentane and a number of higher (>C6) hydrocarbons (Sommariva et al., 2008). From these numbers it can be estimated that about $24-28 \%$ of acetone is produced by the reaction of propane with $\mathrm{OH}$.

The other two significant sources of acetone are the alkoxy radicals $T C 4 H 9 O$, which accounts for $\sim 10 \%$ of the total acetone production, and MIPKAO, which accounts for $\sim 5 \%$ of the total acetone production (Fig. 6). The former is a product of i-butane, 2,2-dimethylbutane and methyl t-butyl ether (MTBE), while the latter is a product of the oxidation of i-pentane and 2,3-dimethylbutane, with minor contributions from 2-methyl-2-butene (Fig. 7).

The analysis of the formation of the IPEBO2 peroxy radical, which is the most important precursor of MIPKAO, discussed in Sommariva et al. (2008) indicates that the reaction between i-pentane and $\mathrm{OH}$ is the most important (>90\%) source of this alkoxy radical. It also indicates that it accounts for a significant fraction of the $20 \%$ of IC $3 H 7 O 2$ not coming from propane reaction with $\mathrm{OH}$. It can therefore be inferred that i-pentane is overall the most important precursor of acetone, followed by propane.

Acetone is also formed by reaction of i-propanol with $\mathrm{OH}$. This pathway accounts for up to $15 \%$ of the total production, decreasing with time to about $6 \%$ as the concentration of ipropanol decreases (Fig. 6). The photochemical production of i-propanol occurs via a peroxy-peroxy reaction involving the IC3H7O2 peroxy radical and it is significant only at low $\mathrm{NO}_{\mathrm{x}}$, i.e. starting from the second day. It is however very slow, because only $20 \%$ of the reaction of IC3H7O2 with other peroxy radicals forms i-propanol. Therefore this source of acetone is largely related to direct emissions of i-propanol (Table 1).

A small fraction $(<5 \%)$ of acetone is produced by a number of larger hydrocarbons, such as 2-methylpentane, 2methylhexane, 2,2-dimethylbutane and other >C6 alkanes and alkenes through a variety of other routes (Fig. 6).

The results of this analysis can be compared to those discussed in Lewis et al. (2005), who studied the formation processes of acetone, acetaldehyde and methanol using measurements taken at Mace Head, on the Western coast of Ireland, and a model based upon the MCM. According to their analysis, the main precursors of acetone are i-pentane, ibutane and propane, either directly or via the formation of stable hydroperoxides. The main difference with the results discussed in this work is the role of i-butane to which Lewis et al. (2005) attributed $27 \%$ of acetone formation on the first day and $22 \%$ on the fifth day (including the contribution by the hydroperoxide). As shown in Fig. 7, i-butane is the major precursor of the TC4H9O alkoxy radical, which, according to the analysis shown here only accounted for about $\sim 10 \%$ of the total acetone formation (Fig. 6). On the other hand, Lewis et al. (2005) attributed only 6-13\% to the reaction of propane with $\mathrm{OH}$ (compared to 24-28\%) and 6-16\% (compared to $<10 \%$ ) to the reaction with the hydroperoxide $\mathrm{IC} 3 \mathrm{H} 7 \mathrm{OOH}$. The role of i-pentane is more difficult to assess, due to the variety of routes. Lewis et al. (2005) calculated about a third (on day 1) to a fifth (on day 5) of acetone being produced via the IPECO pathway (Fig. 7) and another 3-8\% via the $M I P K A O$ pathway. These numbers compare well with those presented in this analysis (Fig. 6, though they neglect minor routes and the contribution of $\mathrm{i}$-pentane to the formation of the $I C 3 H 7 O$ radical (Sommariva et al., 2008).

In short, the analysis by Lewis et al. (2005) shows a larger contribution from i-butane and a smaller contribution from propane compared to this work, but the two analyses agree reasonably well as far as the other acetone formation routes are concerned. Both analyses highlight the role of hydroperoxides in sustaining the formation of acetone after depletion of $\mathrm{NO}_{\mathrm{x}}$ and far from the emission points of the precursors. It must be noted that, while the modelling approach of this study and of that by Lewis et al. (2005) are very similar, the initial conditions used by the two models are different. In this work the initial concentrations of VOCs were derived from the observations, while Lewis et al. (2005) estimated theirs on the basis of the UK emission inventory. In particular, $\mathrm{CO}$, $\mathrm{O}_{3}, \mathrm{NO}_{\mathrm{x}}$, propane and pentane were lower and butane was higher than the values used in this work (Table 1). The differences in the model initialization can largely explain the differences in the results.

Both our analysis and the one by Lewis et al. (2005) indicate a less important role of propane and a more important role of higher alkanes in the photochemical production of acetone compared to the calculations by Jacob et al. (2002). Using the GEOS-CHEM global model and the EDGAR emission inventory, Jacob et al. (2002) calculated 


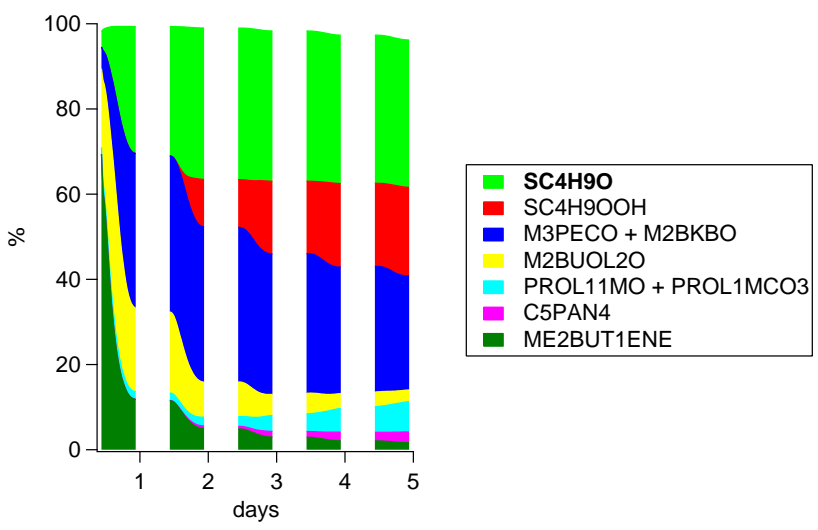

Fig. 8. Relative contribution of reaction pathways to the formation of MEK. See Fig. 9 for explanation of the MCM codenames.

that $\sim 60 \%$ of the photochemical production of acetone from alkanes is due to propane oxidation and about $30 \%$ to butane and pentane oxidation. However, the chemical scheme used in GEOS-CHEM is not as detailed as the MCM.

It must also be noted that 2-methyl-3-buten-2-ol (MBO), which has been identified as an important acetone precursor (Fantechi et al., 1998; Alvarado et al., 1999; Singh et al., 2000; Jacob et al., 2002), was not measured during ICARTT and therefore could not be taken into account in this work.

\subsection{MEK}

Methyl ethyl ketone has a smaller number of precursors and formation pathways than acetone. Besides, while acetone precursors are mostly alkanes (Sect. 4.1), MEK is also formed from alkenes, particularly during the first two days. During the first day, direct oxidation of 2-methyl-1-butene accounts, on average, for $27 \%$ of MEK formation, decreasing to less than $10 \%$ on the second and less than $5 \%$ on the remaining days (Fig. 8). The role of 2-methyl-1-butene is not limited to direct oxidation, because this species is a precursor (though not the only one) of several other intermediates of MEK formation (Fig. 9).

The alkoxy radical $M 2 B U O L 2 O$, for example, is produced from 2-methyl-1-butene during the first day, but from the IPEAO2 peroxy radical from the second day onward (Fig. 9). The M2BUOL2O route accounts for up to $30 \%$ on the first day decreasing with time down to only $3 \%$ of MEK formation on the fifth day (Fig. 8).

The IPEAO2 peroxy radical is mostly formed by the oxidation of i-pentane $(<80 \%)$ and 3-methylpentane $(<20 \%)$. Besides the $M 2 B U O L 2 O$ alkoxy radical, it forms another peroxy radical (BUT2CO3), which is the precursor of a PANlike compound (C5PAN4, Fig. 9), whose reaction with $\mathrm{OH}$ accounts for less than $3 \%$ of MEK formation during the last three days (Fig. 8). Most of BUT2CO3, however, reacts to form another peroxy radical, $\mathrm{SC} 4 \mathrm{H} 9 \mathrm{O} 2$ (Fig. 9). This is a key precursor of MEK, as the reaction of the corresponding alkoxy radical ( $\mathrm{SC} 4 \mathrm{H} 9 \mathrm{O}$ ) with $\mathrm{O}_{2}$ accounts for $20-35 \%$ of the total MEK formation and, after the first day, the reaction of the corresponding hydroperoxide $(\mathrm{SC} 4 \mathrm{H} 9 \mathrm{OOH})$ with $\mathrm{OH}$ accounts for another 10-20\% of the total MEK formation (Fig. 8).

According to the analysis discussed in Sommariva et al. (2008), who used the same model and initial conditions, the formation route of $\mathrm{SC} 4 \mathrm{H} 9 \mathrm{O} 2$ via $\mathrm{BUT} 2 \mathrm{CO} 3$ is secondary and accounts only for $5 \%$ or less. Most of SC4H9O2 (85-95\%) is formed from the oxidation of n-butane. Using these values, it can be estimated that about $20-30 \%$ of MEK is formed from the reaction of $n$-butane with $\mathrm{OH}$.

The other major formation pathways of MEK go via two alkoxy radicals ( $M 3 P E C O$ and $M 2 B K B O$ ), which come both from 3-methylpentane (Fig. 9). Together they account for about $10 \%$ to $30 \%$ on the first day and about $30-40 \%$ on the following days of the total MEK formation (Fig. 8). The most important of the two is M3PECO (Fig. 9). $M 2 B K B O$ becomes significant only after the third day due to its longer formation route, which involves a stable ketone (3-methyl-2pentanone). The ratio of the contributions to MEK formation of these two alkoxy radicals (M3PECO:M2BKBO) is about $85: 15$ during the fourth and fifth days.

Another secondary route for the photochemical formation of MEK is the one via the alkoxy radical PROL11MO and, less importantly, the decomposition of the peroxy radical PROL1MCO3 after reaction with NO. Via different pathways these two intermediates are both produced from the oxidation of 3-methylhexane and, to a lesser extent, 2-methyl1-butene (Fig. 9). Together they account for at most $7 \%$ of the total MEK formation (Fig. 8).

\subsection{Acetaldehyde}

Analysis of acetaldehyde photochemical formation is necessarily more qualitative due to the large number of formation pathways. In this section only the most important pathways will be discussed, neglecting those that contribute less than $5 \%$ to the formation of acetaldehyde.

Approximately half (40-50\%) of acetaldehyde is formed via the reaction of the $\mathrm{C} 2 \mathrm{H} 5 \mathrm{O}$ alkoxy radical with oxygen (Fig. 10). The most important precursor of this alkoxy radical is the $\mathrm{C} 2 \mathrm{H} 5 \mathrm{O} 2$ peroxy radical, whose formation has been described in detail in a previous paper (Sommariva et al., 2008). The corresponding hydroperoxide $(\mathrm{C} 2 \mathrm{H} 5 \mathrm{OOH})$ begins forming on the second day, when the concentration of $\mathrm{NO}_{\mathrm{x}}$ is low and contributes up to $15 \%$ to the formation of acetaldehyde via reaction with $\mathrm{OH}$.

According to the analysis by Sommariva et al. (2008) ethane is a major precursor of $\mathrm{C} 2 \mathrm{H} 5 \mathrm{O} 2$ (15-45\%), together with propanal, MEK and a range of $>\mathrm{C} 5$ alkanes. Therefore the formation of acetaldehyde can be attributed to the reaction of ethane with $\mathrm{OH}$ for about $6 \%$ on the first day increasing to $\sim 23 \%$ on the fifth day. These values agree rather well with those reported by Lewis et al. (2005), though they 


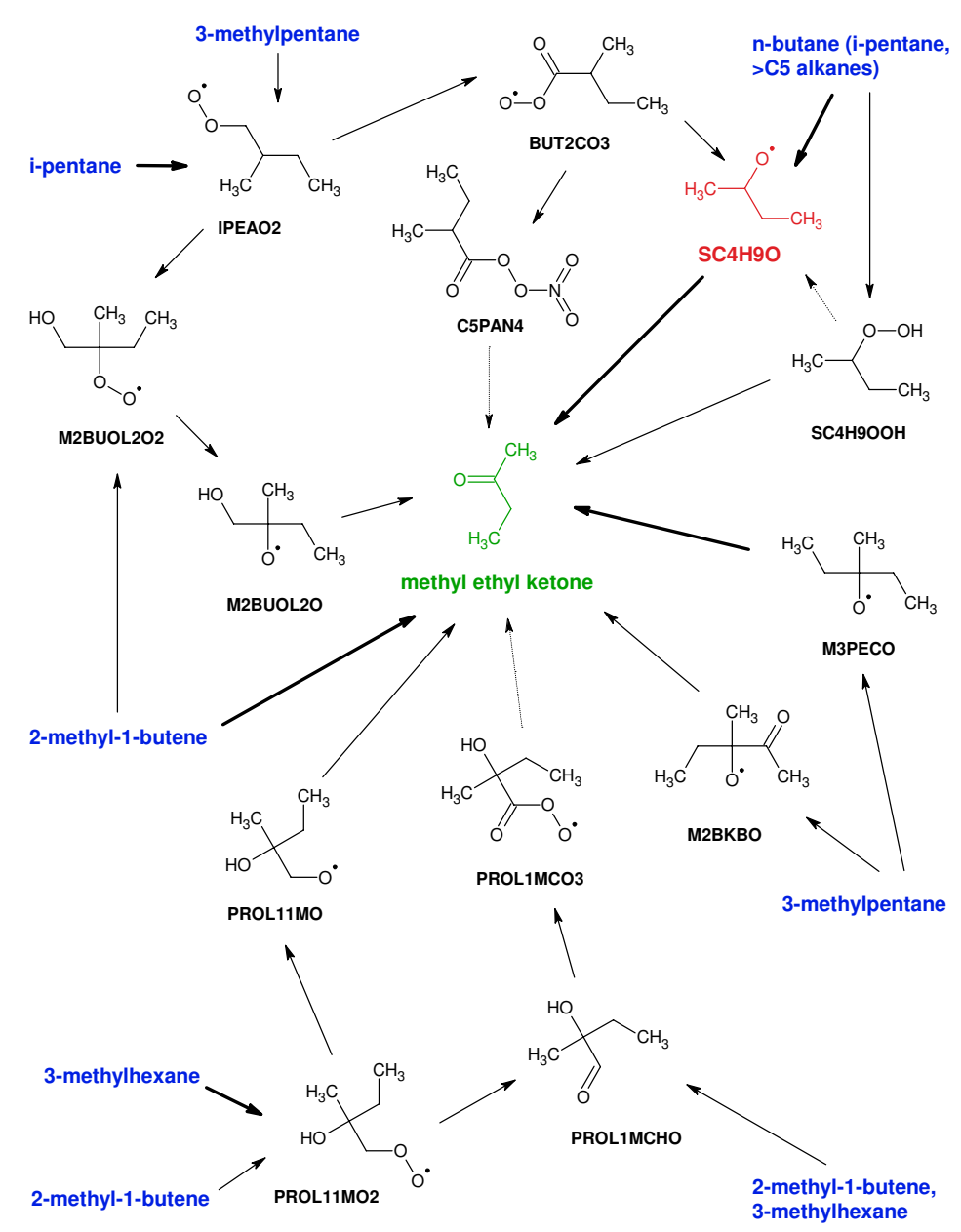

Fig. 9. Reaction scheme for the formation of MEK. Green indicates the target species, blue indicates the VOC precursors and red indicates an intermediate analyzed in detail in Sommariva et al. (2008).

estimated higher $(9.5 \%)$ contribution from ethane on the first day and slight lower $(17.5 \%)$ on the the fifth day.

About $30 \%$ of $\mathrm{C} 2 \mathrm{H} 5 \mathrm{O} 2$ is formed from the $\mathrm{C} 2 \mathrm{H} 5 \mathrm{CO} 3$ peroxy radical, which has a very large number of precursors (including propanal, see Sommariva et al., 2008) and which reacts with $\mathrm{NO}_{2}$ to form PPN. The reaction of PPN with $\mathrm{OH}$ is a minor source of acetaldehyde accounting for 5-7\% of its total formation rate (Fig. 10).

Besides the formation of the $\mathrm{C} 2 \mathrm{H} 5 \mathrm{O} 2$ peroxy radical, MEK contributes to the production of acetaldehyde also by forming most (50-60\%) of the MEKBO alkoxy radical, via reaction with $\mathrm{OH}$. The decomposition of the $M E K B O$ alkoxy radical is a relatively minor formation pathway for acetaldehyde, accounting for $4-7 \%$ of its total formation rate (Fig. 10).

During the first day, propene and other alkenes significantly contribute to the formation of acetaldehyde. Propene accounted for about $9 \%$, butenes for about $7 \%$ and pentenes for about $5 \%$. These numbers are in broad agreement with the results of Lewis et al. (2005), though somewhat higher for propene and the pentenes. Propene is also the most important precursor of the HYPROPO alkoxy radical (Fig. 10), especially during the first two days when its contribution to acetaldehyde formation is most important (up to $25 \%$ ). The role of these species decreases very quickly, because of their high reactivity.

Finally, a significant contribution to the photochemical formation of acetaldehyde comes from the reaction of ethanol with $\mathrm{OH}$ (Fig. 10). This route accounts for $5 \%$ up to $25 \%$ of acetaldehyde formation, peaking on the second day, and it is mostly related to direct emissions of ethanol (Table 1), since its photochemical production is very slow. The role of ethanol emissions in acetaldehyde formation is particularly interesting in view of the possible increase in the use of ethanol as fuel in the next future. Jacobson (2007) estimated that, in a scenario where ethanol replaces gasoline, the increase in atmospheric concentrations of ethanol and acetaldehyde would be of $20 \mathrm{ppbv}$ and $1.5 \mathrm{ppbv}$, respectively, with significant impact on ozone and PAN concentrations. Most of the increase in acetaldehyde concentration would be 


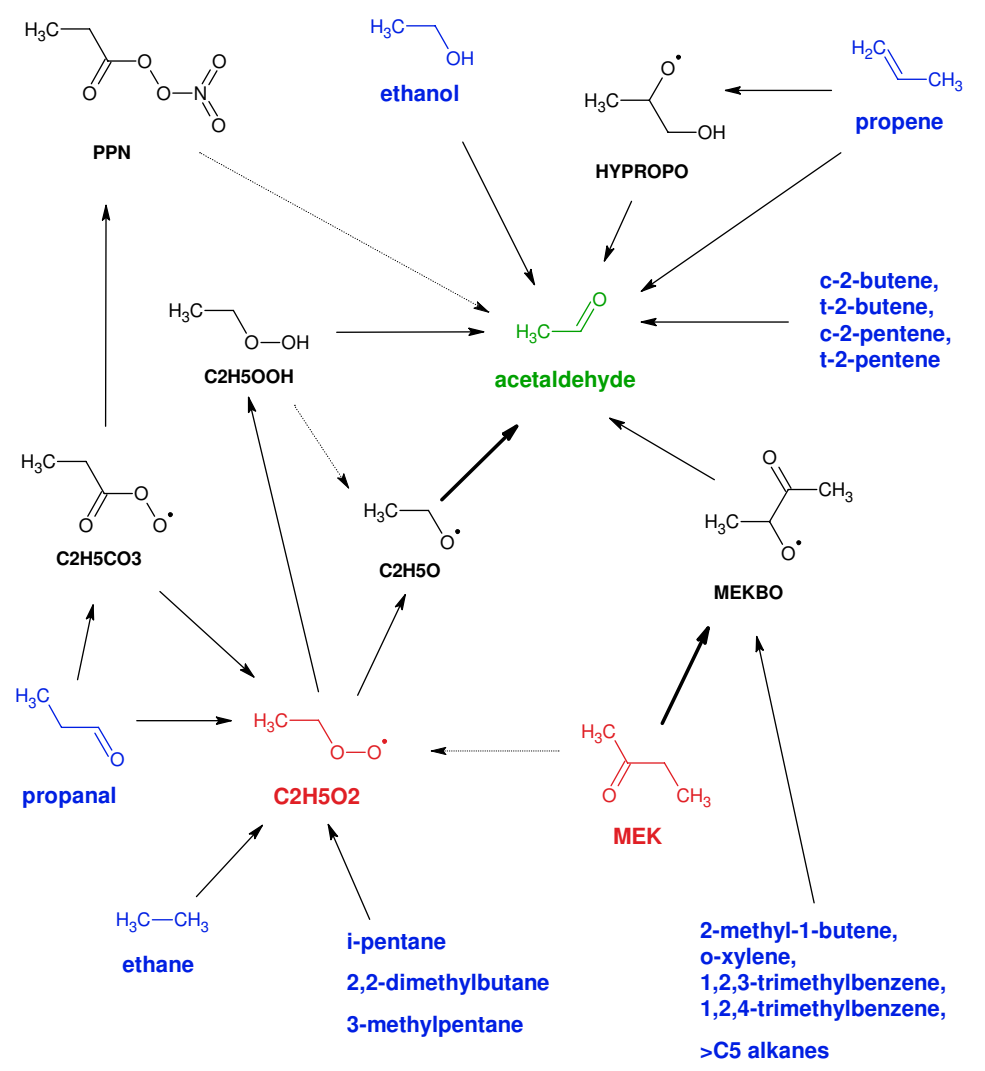

Fig. 10. Reaction scheme for the formation of acetaldehyde. Green indicates the target species, blue indicates the VOC precursors and red indicates an intermediate analyzed in detail in Sommariva et al. (2008).

related to photochemical production (up to three times more important than increased emissions) from unburnt ethanol (Jacobson, 2007). Considering that the initial concentration of ethanol in our model is about 800 pptv (Table 1), the increase predicted by Jacobson (2007) would make ethanol the single most important source of acetaldehyde, largely dominating all the other photochemical sources.

\section{Conclusions}

The photochemical evolution of urban plumes in the Northeast of the United States has been studied using a highly detailed chemical model based upon the Master Chemical Mechanism (MCM). The model has been initialized using measurements and VOC emission ratios from the NEAQS 2002 and ICARTT 2004 field campaigns. The model results have been compared to measurements of oxygenated VOCs taken during the ICARTT field campaign. With the exception of acetic acid, the model underestimates the measured concentrations of oxygenated VOCs by $40-60 \%$, but is able to reproduce their variation in time. The model also agrees very well with a simple empirical parametrization obtained from the measurements taken during a previous field campaign in the same area.

Using the explicit description of the chemistry provided by the MCM, the photochemical formation and the evolution of the most important ketones (acetone and methyl ethyl ketone) has been determined quantitatively and the relative importance of their different formation pathways has been calculated. Approximately $24-28 \%$ of acetone formation can be attributed to the reaction of propane with $\mathrm{OH}$ and about $20-30 \%$ of MEK to the reaction of n-butane with $\mathrm{OH}$. The most important precursor of acetone is i-pentane, via a number of different pathways, while emissions of i-propanol account for up to $15 \%$ of the photochemical production of acetone. Besides n-butane, the most significant precursor of MEK is 3-methylpentane, which accounts for up to $40 \%$ of its total production rate. At low $\left[\mathrm{NO}_{\mathrm{x}}\right]$, the hydroperoxides formed by the reactions of the peroxy radicals with $\mathrm{HO}_{2}$ provide a significant (10-20\%) pathway to the formation of acetone and MEK, sustaining their photochemical production far away from the emission sources.

Acetaldehyde has a very large number of sources, which include propanal, MEK and a range of $>\mathrm{C} 5$ alkanes and some aromatics. The reaction of ethane with $\mathrm{OH}$ accounts 
for $6 \%$ up to $23 \%$ of acetaldehyde formation. During the first two days, alkenes (particularly propene) are also significant sources. Ethanol, which is mostly emitted, accounts for $5 \%$ up to $25 \%$ of acetaldehyde photochemical formation.

Clearly, these results are dependent on the initial conditions used by the model. Depending on the initial $\mathrm{NO}_{\mathrm{x}}$ levels, the low $\mathrm{NO}_{\mathrm{x}}$ formation pathways can become significant later and farther away from the emission sources. The values used in this work are based on measured emission ratios and should be fairly similar for other urban areas characterized by comparable industrial activity and mostly traffic-related emissions.

Acknowledgements. We would like to thank the flight and ground crew of the NOAA WP-3D aircraft for their help during the field campaign.

Edited by: J. Williams

\section{References}

Alvarado, A., Tuazon, E. C., Aschmann, S. M., Arey, J., and Atkinson, R.: Products and mechanisms of the gas-phase reactions of $\mathrm{OH}$ radicals and $\mathrm{O}_{3}$ with 2-methyl-3-buten-2-ol, Atmos. Environ., 33, 2893-2905, 1999.

Atkinson, R. and Arey, J.: Atmospheric degradation of volatile organic compounds, Chem. Rev., 103, 4605-4638, 2003.

Atkinson, R., Baulch, D. L., Cox, R. A., Crowley, J. N., Hampson, R. F., Kerr, J. A., Rossi, M. J., and Troe, J.: Summary of evaluated kinetic and photochemical data for atmospheric chemistry, Tech. rep., IUPAC Subcommittee on Gas Kinetic Data Evaluation for Atmospheric Chemistry, http://www.iupac-kinetic.ch. cam.ac.uk, 2003.

Baeza-Romero, M. T., Blitz, M. A., Heard, D. E., Pilling, M. J., Price, B., Seakins, P. W., and Wang, L. M.: Photolysis of methylethyl, diethyl and methylvinyl ketones and their role in the atmospheric $\mathrm{HO}_{\mathrm{x}}$ budget, Faraday Discuss., 130, 73-88, 2005.

Barsanti, K. C. and Pankow, J. F.: Thermodynamics of the formation of atmospheric organic particulate matter by accretion reactions - Part 1: aldehydes and ketones, Atmos. Environ., 38, 4371-4382, 2004.

Carpenter, L. J., Lewis, A. C., Hopkins, J. R., Read, K. A., Longley, I. D., and Gallagher, M. W.: Uptake of methanol to the North Atlantic Ocean surface, Global Biogeochem. Cy., 18, GB4027, doi:10.1029/2004GB002294, 2004.

Colomb, A., Williams, J., Crowley, J., Gros, V., Hofmann, R., Salisbury, G., Klupfel, T., Kormann, R., Stickler, A., Forster, C., and Lelieveld, J.: Airborne measurements of trace organic species in the upper troposphere over Europe: the impact of deep convection, Environ. Chem., 3, 244-259, 2006.

Daum, P. H., Kleinman, L. I., Newman, L., Luke, W. T., WeinsteinLloyd, J., Berkowitz, C. M., and Busness, K. M.: Chemical and physical properties of plumes of anthropogenic pollutants transported over the North Atlantic during the North Atlantic Regional Experiment, J. Geophys. Res., 101, 29029-29042, 1996.

de Gouw, J. A. and Warneke, C.: Measurements of volatile organic compounds in the Earth's atmosphere using proton-transfer- reaction mass spectrometry, Mass Spectrom. Rev., 26, 223-257, 2007.

de Gouw, J. A., Middlebrook, A. M., Warneke, C., Goldan, P. D., Kuster, W., Roberts, J. M., Fehsenfeld, F. C., Worsnop, D. R., Canagaratna, M., Pszenny, A. A. P., Keene, W. C., Marchewka, M., Bertman, S. B., and Bates, T. S.: Budget of organic carbon in a polluted atmosphere: results from the New England Air Quality Study in 2002, J. Geophys. Res., 110, D16305, doi:10.1029/2004JD005623, 2005.

de Gouw, J. A., Warneke, C., Stohl, A., Wollny, A. G., Brock, C. A., Cooper, O. R., Holloway, J. S., Trainer, M., Fehsenfeld, F. C., Atlas, E. L., Donnelly, S. G., Stroud, V., and Lueb, A.: Volatile organic compounds composition of merged and aged forest fire plumes from Alaska and western Canada, J. Geophys. Res., 111, D10303, doi:10.1029/2005JD006175, 2006.

de Gouw, J. A., Brock, C. A., Atlas, E. L., Bates, T. S., Fehsenfeld, F. C., Goldan, P. D., Holloway, J. S., Kuster, W. C., Lerner, B. M., Matthew, B. M., Middlebrook, A. M., Onasch, T. B., Peltier, R. E., Quinn, P. K., Senff, C. J., Stohl, A., Sullivan, A. P., Trainer, M., Warneke, C., Weber, R. J., and Williams, E. J.: Sources of particulate matter in the northeastern United States in summer: 1. Direct emissions and secondary formation of organic matter in urban plumes, J. Geophys. Res., 113, D08301, doi:10.1029/2007JD009243, 2008.

Emmerson, K. M., Carslaw, N., and Pilling, M. J.: Urban atmospheric chemistry during the PUMA campaign 2: radical budgets for $\mathrm{OH}, \mathrm{HO}_{2}$ and $\mathrm{RO}_{2}$, J. Atmos. Chem., 52, 165-183, 2005.

Fantechi, G., Jensen, N. R., Hjorth, J., and Peeters, J.: Mechanistic studies of the atmospheric oxidation of methyl butenol by $\mathrm{OH}$ radicals, ozone and $\mathrm{NO}_{3}$ radicals, Atmos. Environ., 32, 35473556, 1998.

Fehsenfeld, F. C., Ancellet, G., Bates, T. S., Goldstein, A. H., Hardesty, R. M., Honrath, R., Law, K. S., Lewis, A. C., Leaitch, R., McKeen, S., Meagher, J., Parrish, D. D., Pszenny, A. A. P., Russel, P. B., Schlager, H., Seinfeld, J., Talbot, R., and Zbinden, R.: International Consortium for Atmospheric Research on Transport and Transformation (ICARTT): North America to Europe Overview of the 2004 summer field study, J. Geophys. Res., 111, D23S01, doi:10.1029/2006JD007829, 2006.

Goldan, P. D., Kuster, W. C., Williams, E., Murphy, P. C., Fehsenfeld, F. C., and Meagher, J.: Nonmethane hydrocarbon and oxy hydrocarbon measurements during the $2002 \mathrm{New}$ England Air Quality Study, J. Geophys. Res., 109, D21309, doi:10.1029/2003JD004455, 2004.

Hamilton, J. F., Webb, P. J., Lewis, A. C., Hopkins, J. R., Smith, S., and Davy, P.: Partially oxidised organic components in urban aerosol using GCxGC-TOF/MS, Atmos. Chem. Phys., 4, 12791290, doi:10.5194/acp-4-1279-2004, 2004.

Helas, G., Bingemer, H., and Andreae, M. O.: Organic acids over equatorial Africa: results from DECAFE 88, J. Geophys. Res., 97, 6187-6193, 1992.

Ito, A., Sillman, S., and Penner, J. E.: Effects of additional nonmethane volatile organic compounds, organic nitrates, and direct emissions of oxygenated organic species on global tropospheric chemistry, J. Geophys. Res., 112, D06309, doi:10.1029/2005JD006556, 2007.

Jacob, D. J., Wofsy, S. C., Bakwin, P. S., Fan, S.-M., Harriss, R. C., Talbot, R. W., Bradshaw, J. D., Sandholm, S. T., Singh, H. B., Browell, E. V., Gregory, G. L., Sachse, G. W., Shipman, M. C., 
Blake, D. R., and Fitzjarrald, D. R.: Summertime photochemistry of the troposphere at high northern latitudes, J. Geophys. Res., 97, 16421-16431, 1992.

Jacob, D. J., Field, B. D., Jin, E. M., Bey, I., Li, Q., Logan, J. A., and Yantosca, R. M.: Atmospheric budget of acetone, J. Geophys. Res., 107, 4100, doi:10.1029/2001JD000694, 2002.

Jacobson, M. Z.: Effects of ethanol (E85) versus gasoline vehicles on cancer and mortality in the United States, Environ. Sci. Technol., 41, 4150-4157, 2007.

Jaeglé, L., Jacob, D. J., Brune, W. H., and Wennberg, P. O.: Chemistry of $\mathrm{HO}_{\mathrm{x}}$ radicals in the upper troposphere, Atmos. Environ., 35, 469-489, 2001.

Jenkin, M. E., Saunders, S. M., and Pilling, M. J.: The tropospheric degradation of volatile organic compounds: a protocol for mechanism development, Atmos. Environ., 31, 81-104, 1997.

Jenkin, M. E., Saunders, S. M., Wagner, V., and Pilling, M. J.: Protocol for the development of the Master Chemical Mechanism, MCM v3 (Part B): tropospheric degradation of aromatic volatile organic compounds, Atmos. Chem. Phys., 3, 181-193, doi:10.5194/acp-3-181-2003, 2003.

Kesselmeier, J.: Exchange of short-chain oxygenated volatile organic compounds (VOCs) between plants and the atmosphere: a compilation of field and laboratory studies, J. Atmos. Chem., 39, 219-233, 2001.

Klemm, O., Talbot, R. W., Fitzgerald, D. R., Klemm, K. I., and Lefer, B. L.: Low to middle tropospheric profiles and biosphere/troposphere flux of acidic gases in the summertime Canadian taiga, J. Geophys. Res., 99, 1687-1698, 1994.

Lewis, A. C., Hopkins, J. R., Carpenter, L. J., Stanton, J., Read, K. A., and Pilling, M. J.: Sources and sinks of acetone, methanol, and acetaldehyde in North Atlantic air, Atmos. Chem. Phys., 5, 1963-1974, doi:10.5194/acp-5-1963-2005, 2005.

Madronich, S.: Chemical evolution of gaseous air pollutants downwind of tropical megacities: Mexico City case study, Atmos. Environ., 40, 6012-6018, 2006.

Madronich, S., Chatfield, R. B., Calvert, J. G., Moortgat, G. K., Veyret, B., and Lesclaux, R.: A photochemical origin of acetic acid in the troposphere, Geophys. Res. Lett., 17, 2361-2364, 1990.

Marandino, C. A., Bruyn, W. J. D., Miller, S. D., Prather, M. J., and Saltzman, E. S.: Oceanic uptake and the global atmospheric acetone budget, Geophys. Res. Lett., 32, L15806, doi:10.1029/2005GL023285, 2005.

McKeen, S. A. and Liu, S. C.: Hydrocarbon ratios and photochemical history of air masses, Geophys. Res. Lett., 20, 2363-2366, 1993.

McKeen, S. A., Liu, S. C., Hsie, E. Y., Lin, X., Bradshaw, J. D., Smyth, S., Gregory, G. L., and Blake, D. R.: Hydrocarbon ratios during PEM-WEST A: a model perspective, J. Geophys. Res., 101, 2087-2109, 1996.

McKeen, S. A., Gierczak, T., Burkholder, J. B., Wennberg, P. O., Hanisco, T. F., Keim, E. R., Gao, R. S., Ravishankara, A. R., and Fahey, D. W.: The photochemistry of acetone in the upper troposphere: a source of odd-hydrogen radicals, Geophys. Res. Lett., 24, 3177-3180, 1997.

Müller, K., Haferkorn, S., Grabmer, W., Whisthaler, A., Hansel, A., Kreuzwieser, J., Cojocariu, C., Rennenberg, H., and Herrmann, H.: Biogenic carbonyl compounds within and above a coniferous forest in Germany, Atmos. Environ., 40, 81-91, 2006.
Neuman, J. A., Parrish, D. D., Trainer, M., Ryerson, T. B., Holloway, J. S., Nowak, J. B., Swanson, A., Flocke, F., Roberts, J. M., Brown, S. S., Stark, H., Sommariva, R., Stohl, A., Peltier, R., Weber, R., Wollny, A. G., Sueper, D. T., Hübler, G., and Fehsenfeld, F. C.: Reactive nitrogen transport and photochemistry in urban plumes over the North Atlantic Ocean, J. Geophys. Res., 111, D23S54, doi:10.1029/2005JD007010, 2006.

Nolte, C. G., Solomon, P. A., Fall, T., Salmon, L. G., and Cass, G. R.: Seasonal and spatial characteristics of formic and acetic acids concentrations in the Southern California atmosphere, Environ. Sci. Technol., 31, 2547-2553, 1997.

Northway, M. J., de Gouw, J. A., Fahey, D. W., Gao, R. S., Warneke, C., Robert, J. M., and Flocke, F.: Evaluation of the role of heterogeneous oxidation of alkenes in the detection of atmospheric acetaldehyde, Atmos. Environ., 38, 6017-6028, 2004.

Odabasi, M. and Seyfioglu, R.: Phase partitioning of atmospheric formaldehyde in a suburban atmosphere, Atmos. Environ., 39, 5149-5156, 2005.

Olson, J. R., Crawford, J. H., Chen, G., Fried, A., Evans, M. J., Jordan, C. E., Sandholm, S. T., Davis, D. D., Anderson, B. E., Avery, M. A., Barrick, J. D., Blake, D. R., Brune, W. H., Eisele, F. L., Flocke, F., Harder, H., Jacob, D. J., Kondo, Y., Lefer, B. L., Martinez, M., Mauldin, R. L., Sachse, G. W., Shetter, R. E., Singh, H. B., Talbot, R. W., and Tan, D.: Testing fast photochemical theory during TRACE-P based on measurements of $\mathrm{OH}, \mathrm{HO}_{2}$ and $\mathrm{CH}_{2} \mathrm{O}$, J. Geophys. Res., 109, D15S10, doi:10.1029/2003JD004278, 2004.

Parrish, D. D., Stohl, A., Forster, C., Atlas, E. L., Blake, D. R., Goldan, P. D., Kuster, W. C., and de Gouw, J. A.: Effects of mixing on evolution of hydrocarbon ratios in the troposphere, J. Geophys. Res., 112, D10S34, doi:10.1029/2006JD007583, 2007.

Reeves, C. E., Slemr, J., Oram, D. E., Worton, D., Penkett, S. A., Stewart, D. J., Purvis, R., Watson, N., Hopkins, J., Lewis, A., Methven, J., Blake, D. R., and Atlas, E.: Alkyl nitrates in outflow from North America over the North Atlantic during Intercontinental Transport of Ozone and Precursors 2004, J. Geophys. Res., 112, D10S37, doi:10.1029/2006JD007567, 2007.

Roberts, J. M., Marchewka, M., Bertman, S. B., Sommariva, R., Warneke, C., de Gouw, J. A., Kuster, W. C., Goldan, P. D., Williams, E. J., Lerner, B. M., Murphy, P., and Fehsenfeld, F. C.: Measurements of PANs during the New England Air Quality Study 2002, J. Geophys. Res., 112, D20306, doi:10.1029/2007JD008667, 2007.

Saunders, S. M., Jenkin, M. E., Derwent, R. G., and Pilling, M. J.: Protocol for the development of the Master Chemical Mechanism, MCM v3 (Part A): tropospheric degradation of nonaromatic volatile organic compounds, Atmos. Chem. Phys., 3, 161-180, doi:10.5194/acp-3-161-2003, 2003.

Schauffler, S., Atlas, E. L., Blake, D. R., Flocke, F., Lueb, R. A., Lee-Taylor, J. M., Stroud, V., and Travicek, W.: Distribution of brominated organic compounds in the troposphere and lower stratosphere, J. Geophys. Res., 104, 21513-21535, 1999.

Singh, H., Chen, Y., Tabazadeh, A., Fukui, Y., Bey, I., Yantosca, R., Jacob, D., Arnold, F., Wohlfrom, K., Atlas, E., Flocke, F., Blake, D., Blake, N., Heikes, B., Snow, J., Talbot, R., Gregory, G., Sachse, G., Vay, S., and Kondo, Y.: Distribution and fate of selected oxygenated organic species in the troposphere and lower stratosphere over the Atlantic, J. Geophys. Res., 105, 3795-3805, 2000. 
Singh, H., Chen, Y., Staudt, A., Jacob, D., Blake, D., Heikes, B., and Snow, J.: Evidence from the Pacific troposphere for large global sources of oxygenated organic compounds, Nature, 410, 1078-1081, 2001.

Singh, H. B., O'Hara, D., Herlth, D., Sachse, W., Blake, D. R., Bradshaw, J. D., Kanakidou, M., and Crutzen, P. J.: Acetone in the atmosphere: distribution, sources and sinks, J. Geophys. Res., 99, 1805-1819, 1994.

Singh, H. B., Kanakidou, M., Crutzen, P. J., and Jacob, D. J.: Highconcentrations and photochemical fate of oxygenated hydrocarbons in the global troposphere, Nature, 378, 50-54, 1995.

Singh, H. B., Salas, L. J., Chatfield, R. B., Czech, E., Fried, A., Walega, J., Evans, M. J., Field, B. D., Jacob, D. J., Blake, D., Heikes, B., Talbot, R., Sachse, G., Crawford, J. H., Avery, M., Sandholm, S., and Fuelberg, H.: Analysis of the atmospheric distribution, sources and sinks of oxygenated volatile organic chemicals based on measurements over the Pacific during TRACEP, J. Geophys. Res., 109, D15S07, doi:10.1029/2003JD003883, 2004.

Sommariva, R., Bloss, W. J., Brough, N., Carslaw, N., Flynn, M., Haggerstone, A.-L., Heard, D. E., Hopkins, J. R., Lee, J. D., Lewis, A. C., McFiggans, G., Monks, P. S., Penkett, S. A., Pilling, M. J., Plane, J. M. C., Read, K. A., Saiz-Lopez, A., Rickard, A. R., and Williams, P. I.: $\mathrm{OH}$ and $\mathrm{HO}_{2}$ chemistry during NAMBLEX: roles of oxygenates, halogen oxides and heterogeneous uptake, Atmos. Chem. Phys., 6, 1135-1153, doi:10.5194/acp-6-1135-2006, 2006.

Sommariva, R., Trainer, M., de Gouw, J. A., Roberts, J. M., Warneke, C., Atlas, E., Flocke, F., Goldan, P. D., Kuster, W. C., Swanson, A. L., and Fehsenfeld, F. C.: A study of organic nitrates formation in an urban plume using a Master Chemical Mechanism, Atmos. Environ., 42, 5771-5786, 2008.

Stohl, A., Forster, C., Eckhardt, S., Spichtinger, N., Huntrieser, H., Heland, J., Schlager, H., Wilhelm, S., Arnold, F., and Cooper, O.: A backward modeling study of intercontinental pollution transport using aircraft measurements, J. Geophys. Res., 108, 4370, doi:10.1029/2002JD002862, 2003.

Talbot, R. W., Vijgen, A. S., and Harriss, R. C.: Soluble species in the Arctic summer troposphere: acidic gases, aerosols, and precipitation, J. Geophys. Res., 97, 16531-16543, 1992.

Talbot, R. W., Mosher, B. W., Heikes, B. G., Jacob, D. J., Munger, J. W., Daube, B. C., Keene, W. C., Maben, J. R., and Artz, R. S.: Carboxylic acids in the rural continental atmosphere over the eastern United States during the Shenandoah Cloud and Photochemistry Experiment, J. Geophys. Res., 100, 9335-9343, 1995.

Talbot, R. W., Dibb, J. E., Scheuer, E. M., Blake, D. R., Blake, N. J., Gregory, G. L., Sachse, G. W., Bradshaw, J. D., Sandholm, S. T., and Singh, H. B.: Influence of biomass combustion emissions on the distribution of acidic trace gases over the southern Pacific basin during austral springtime, J. Geophys. Res., 104, 56235634, 1999.
Tong, C., Blanco, M., Goddard, W. A., and Seinfeld, J. H.: Secondary organic aerosol formation by heterogeneous reactions of aldehydes and ketones: a quantum mechanical study, Environ. Sci. Technol., 40, 2333-2338, 2006.

Turpin, E., Tomas, A., Fittschen, C., Devolder, P., and Galloo, J.-C.: Acetone-h6 or $-\mathrm{d} 6+\mathrm{OH}$ reaction products: evidence for heterogeneous formation of acetic acid in a simulation chamber, Environ. Sci. Technol., 40, 5956-5961, 2006.

Warneke, C. and de Gouw, J. A.: Organic trace gas composition of the marine boundary layer over the northwest Indian Ocean in April 2000, Atmos. Environ., 35, 5923-5933, 2001.

Warneke, C., McKeen, S. A., de Gouw, J. A., Goldan, P. D., Kuster, W. C., Holloway, J. S., Williams, E. J., Lerner, B. M., Parrish, D. D., Trainer, M., Fehsenfeld, F. C., Kato, S., Atlas, E. L., Baker, A., and Blake, D. R.: Determination of urban volatile organic compound emission ratios and comparison with an emission database, J. Geophys. Res., 112, D10S47, doi:10.1029/2006JD007930, 2007.

Wennberg, P. O., Hanisco, T. F., Jaeglé, L., Jacob, D. J., Hintsa, E. J., Lanzendorf, E. J., Anderson, J. G., Gao, R.-S., Keim, E. R., Donnelly, S. G., Negro, L. A. D., Fahey, D. W., McKeen, S. A., Salawitch, R. J., Webster, C. R., May, R. D., Herman, R. L., Proffitt, M. H., Margitan, J. J., Atlas, E. L., Schauffler, S. M., Flocke, F., McElroy, C. T., and Bui, T. P.: Hydrogen radicals, nitrogen radicals, and the production of $\mathrm{O}_{3}$ in the upper troposphere, Science, 279, 49-53, 1998.

Yokelson, R. J., Goode, J. G., Ward, D. E., Susott, R. A., Babbitt, R. E., Wade, D. D., Bertschi, I., Griffith, D. W. T., and Hao, W. M.: Emissions of formaldehyde, acetic acid, methanol, and other trace gases from biomass fires in North Carolina measured by airborne Fourier transform infrared spectroscopy, J. Geophys. Res., 104, 30109-30125, 1999.

Zhang, Q., Jimenez, J. L., Canagaratna, M. R., Allan, J. D., Coe, H., Ulbrich, I., Alfarra, M. R., Takami, A., Middlebrook, A. M., Sun, Y. L., Dzepina, K., Dunlea, E., Docherty, K., DeCarlo, P. F., Salcedo, D., Onasch, T., Jayne, J. T., Miyoshi, T., Shimono, A., Hatakeyama, S., Takegawa, N., Kondo, Y., Schneider, J., Drewnick, F., Borrmann, S., Weimer, S., Demerjian, K., Williams, P., Bower, K., Bahreini, R., Cottrell, L., Griffin, R. J., Rautiainen, J., Sun, J. Y., Zhang, Y. M., and Worsnop, D. R.: Ubiquity and dominance of oxygenated species in organic aerosols in anthropogenically-influenced Northern Hemisphere midlatitudes, Geophys. Res. Lett., 34, L13801, doi:10.1029/2007GL029979, 2007. 